\title{
Irfani
}

ISSN 1907-0969 E ISSN 2442-8272

Volume 15 Nomor 1 Juni 2019

Halaman 98-121

http://journal.iaingorontalo.ac.id/index.php/ir

\section{Implementasi Kinerja Guru Tersertifikasi Dalam Pengelolaan Pembelajaran di SMP Negeri Sinombayuga Posigadan}

\author{
Hairun Naus, Siti Asiah T. Pido, Arten H. Mobonggi \\ Pascasarjana IAIN Sultan Amai Gorontalo \\ email: hairunnaus14@gmail.com
}

\begin{abstract}
ABSTRAK
Tujuan penelitian ini adalah untuk mendeskripsikan kinerja guru Tersertifikasi dalam pengelolaan pembelajaran di SMP Negeri Sinombayuga Kabupaten Bolaang Mongondow Selatan, serta mengidentifikasi hambatan dan solusi terhadap kinerja guru.Metode penelitian yang digunakan adalah kualitatif, dengan prosedur pengumpulan data melalui observasi, wawancara dan dokumentasi. Analisis data menggunakan teknik analisis deskriptif kualitatif yang dilakukan dengan memberikan makna terhadap informasi data yang berhasil dikumpulkan, dan dari makna itulah ditarik kesimpulan.Hasil penelitian menunjukkan bahwa: Implementasi kinerja guru tersertifikasi dalam pengelolaan pembelajaran di SMP Negeri Sinombayuga Kecamatan Posigadan, berdasarkan hasil Penilaian Kinerja Guru (PKG) pada semester Ganjil Tahun Pelajaran 2019/2020, rata-rata keseluruhan komponen yang dinilai untuk kompetensi pedagogik dan professional yaitu 88.68 (Sangat Baik), hasil penilaian Kompetensi Kepribadian 91,66 (Sangat Baik), dan hasil penilaian kompetensi sosial 92,86 (Sangat Baik).
\end{abstract}

Kata Kunci: Kinerja Guru, Sertifikasi, Pengelolaan Pembelajaran

\section{PENDAHULUAN}

Kinerja seorang guru yang diharapkan saat ini sesuai dengan amanah undang-undang RI No. 14 tahun 2005 Tentang guru dan dosen lebih diarahkan pada professional pekerjaanatau kegiatan yang dilakukan dan memerlukan keahlian, kemahiran atau kecakapan yang memenuhi standard mutu atau norma tertetntu sehingga memerlukan pendidikan profesi. dengan kegiatan kebijakan pemerintah dalam hal memenuhi tingkat profesionalisme guru yang ahli dalam bidangnya harus mendapat pengakuan keahlian atau disebut dengan legalitas sertifikasi guru. ${ }^{1}$

1 Lihat, Undang-Undang RI nomor 14 Tahun 2005 tentang Guru dan Dosen Pasal7 (cet.11,,Bandung: Pustaka Pelajar, 2009), h.11. 


\section{Irfani}

ISSN 1907-0969 E ISSN 2442-8272

Volume 15 Nomor 1 Juni 2019

Halaman 98-121

http://journal.iaingorontalo.ac.id/index.php/ir

Berdasarkan Undang-Undang No. 14 Tahun 2005 tentang Guru dan Dosen disahkan pada Desember 2005 dinyatakan bahwa standar prestasi kerja guru dalam melaksanakan tugas keprofesionalannya, guru berkewajiban merencanakan pembelajaran, melaksanakan proses pembelajaran yang bermutu serta menilai dan mengevaluasi hasil pembelajaran. Tugas pokok guru tersebut yang diwujudkan dalam kegiatan belajar mengajar merupakan bentuk kinerja guru. Dengan diberlakukan Undang-Undang No. 14 Tahun 2005 tentang Guru dan Dosen minimal memiliki tiga fungsi. Pertama sebagai landasan yuridis bagi guru dari perbuatan semena-mena dari siswa, orang tua dan masyarakat. Kedua untuk meningkatkan profesionalisme guru. Ketiga untuk meningkatkan kesejahteraan guru, baik yang berstatus sebagai Pegawai Negeri Sipil (PNS) ataupun non PNS.

Dalam rangka peningkatan kemampuan profesional guru, perlu dilakukan sertifikasi dan diuji kompetensi secara berkala agar kinerjanya terus meningkat dan tetap memenuhi syarat profesional. Di masa depan profil kelayakan guru akan ditekankan aspek-aspek kemampuan membelajarkan siswa, dimulai dari menganalisis, merencanakan, mengembangkan, mengimplementasikan, dan meniai pembelajaran yang berbasis pada penerapan teknologi pendidikan. Untuk kepentingan tersebut diperlukan suatu kebijakan pendidikan dalam rangka mengembangkan kompetensi diantaranya; Kompentensi Pedagogik, kompetenskepribadian, kompetensi profesional, kompetensi sosial guru menuju keprofesionalan. $^{2}$

Guru merupakan salah satu faktor yang berpengaruh terhadap terciptanya proses dan hasil pendidikan yang berkualitas. Upaya perbaikan apapun yang dilakukan untuk meningkatkan kualitas pendidikan tidak akan memberikan sumbangsi yang signifikan tanpa didukung oleh guru yang profesional. Guru yang memberikan keteladanan, membangun kemauan, dan mengembangankan potensi dan kreativitas peserta didik sangat diperlukan dalam proses suatu pendidikan. Inplementasi dari prinsip ini adalah pergeseran paradigma proses pendidikan, yaitu dari paradigma pengajaran ke paradigma pembelajaran. Proses pembelajaran adalah proses interaksi peserta didik dengan guru dan sumber belajar pada suatu lingkungan belajar. Proses pembelajaran perlu di rencanakan, dilaksanakan, dinilai, dan diawasi agar terlaksana secara efektif dan efisien ${ }^{3}$.

Tugas dan peranan guru sebagai pendidik profesional meliputi kegiatan berlangsungnya interaksi edukatif di dalam kelas, yang umum disebut proses pembelajaran, administrator, evaluator, dan konselor sesuai dengan kompetensi

${ }^{2}$ E. Mulyasa, Standar Kompetensi dan Sertifikasi guru, (Bandung: Rosdakarya, 2008)., h. 13

3 Mulyasa, E. Menjadi Guru Profesional. Menciptakan Pembelajaran Kreatif dan Menyenangkan. (Bandung: PT Remaja Rosdakarya, 2007), h. 41 


\section{Irfani}

ISSN 1907-0969 E ISSN 2442-8272

Volume 15 Nomor 1 Juni 2019

Halaman 98-121

http://journal.iaingorontalo.ac.id/index.php/ir

yang dimilikinnya. ${ }^{4}$ Dalam mengelola pembelajaran, guru hendaknya melaksanakan pembelajaran dengan lebih efektif, dinamis, dan efisien. Hal ini ditandai dengan adanya keterlibatan aktif diantara dua subjek yaitu guru sebagai pembimbing dan pengarah, sedangkan siswa terlibat aktif untuk memperoleh perubahan diri dalam pengajaran. ${ }^{5}$

\section{KINERJA GURU TERSERTIFIKASI}

Kinerja merupakan terjemahan dari kata performance (Job Performance), secara etimologis performance berasal dari kata to perform yang berarti menampilkan atau melaksanakan, sedang kata performance berarti "The act of performing; execution"(Webster Super New School and Office Dictionary), menurut Henry Bosley Woolf Performance berarti "The execution of an action" (Webster New Collegiate Dictionary). Dari pengertian tersebut dapat disimpulkan bahwa kinerja atau performance berarti tindakan menampilkan atau melaksanakan suatu kegiatan, oleh karena itu performance sering juga diartikan penampilan kerja atau prilaku kerja. ${ }^{6}$

Bernardin dalam Sudarmanto mengemukakan bahwa kinerja merupakan catatan hasil yang diproduksi (dihasilkan) atas fungsi pekerjaan tertentu atau aktivitas-aktivitas selama periode waktu tertentu. Sehingga kinerja merupakan suatu hasil yang dicapai seseorang menurut ukuran yang berlaku untuk pekerjaan yang bersangkutan. ${ }^{7}$ Oleh karena itu, kinerja bukan hanya menyangkut karakteristik pribadi yang ditujukan oleh seseorang, melainkan hasil kerja yang telah dan akan dilakukan oleh seseorang. Bila dikaitkan dengan guru maka kinerja guru tidak lain adalah kemampuan guru untuk menampilkan atau mengerjakan tugas guru. Guru mempunyai tugas untuk mendidik, mengajar, dan melatih. Mendidik berarti meneruskan dan mengembangkan nilai-nilai hidup, mengajar berarti meneruskan dan mengembangkan pemahaman siswa terhadap ilmu pengetahuan dan teknologi, sedangkan melatih berarti mengembangkan keterampilan-keterampilan pada peserta didik. ${ }^{8}$

Kinerja guru menurut konsep Dunkin dan Biddle lebih menekankan pada variabel proses lebih penting dari pada variabel produk. Variabel proses merujuk

\footnotetext{
${ }^{4}$ Suryosubroto, Proses Belajar Mengajar Di Sekolah. Wawasan Baru, Beberapa Metode Pendukung dan Beberapa Komponen Layanan Khusus (Jakarta: PT Rineka Cipta. 2009), h. 76

5 Rohani, Ahmad. Pengelolaan Pembelajaran. (Jakarta: PT Rineka Cipta. 2004), h. 102

${ }^{6}$ Siti Asiah T., Efektivitas Kinerja Guru, Tadbir" Jurnal Manajemen Pendidikan Islam Volume 5 No. 2 Agustus 2016, h. 1, http://journal.iaingorontalo.ac.id/index.php/tjmpi/ article/view/435/343, diakses 10-01-2020.

7 Sudarmanto, Kinerja dan Pengembangan Kompetensi SDM, (Yogyakarta: Pustaka Pelajar, 2009), h. 8.

${ }^{8}$ Mohd. Uzer Usman, Menjadi Guru Profesional, (Bandung: PT. Remaja Rosdakarya, 2003), h. 7.
} 


\section{Irfani}

ISSN 1907-0969 E ISSN 2442-8272

Volume 15 Nomor 1 Juni 2019

Halaman 98-121

http://journal.iaingorontalo.ac.id/index.php/ir

pada tingkah laku guru dalam mengajar dan atau melatih mulai dari merencanakan, mempersiapkan dan melaksanakan pembelajaran di dalam kelas. ${ }^{9}$

Berdasarkan Peraturan Menteri Pendidikan Nasional Republik Indonesia Nomor 16 Tahun 2007 tentang Standar Kualifikasi Akademik dan Kompetensi Guru dalam Direktorat Tenaga Kependidikan Departemen Pendidikan Nasional menjelaskan bahwa Standar Kompetensi Guru dikembangkan secara utuh yang berintegrasi dalam kinerja guru, antara lain:

\section{a. Kompetensi Kepribadian}

Kompetensi kepribadian merupakan penguasaan kepribadian yang mantap, stabil, dewasa, arif dan berwibawa, menjadi teladan bagi peserta didik dan berakhlak mulia. Kepribadian adalah keadaan manusia sebagai perseorangan dan keseluruhan sifat yang merupakan watak orang artinya; orang yang baik sifatnya dan wataknya. Kepribadian sangat menentukan tinggi rendahnya seorang guru dalam pandangan anak didik atau masyarakat. Kepribadian merupakan salah satu unsur yang menentukan keakraban hubungan guru dan murid yang tercermin dalam sikap dan perbuatannya dalam membina dan membimbing anak didik. ${ }^{10}$ Kompetensi kepribadian merupakan kemampuan personal yang mencerminkan kepribadian yang mantap, stabil, dewasa, arif, dan berwibawa, menjadi teladan bagi siswa, dan berakhlak mulia. ${ }^{11}$

\section{b. Kompetensi Sosial}

Guru merupakan makhluk sosial. Kehidupan kesehariannya tidak dapat dipisahkan dari kehidupan bersosial, baik di sekolah ataupun di masyarakat. Maka dari itu, Kompetensi sosial sangat perlu dan harus dimiliki seorang guru. Sebab, bagaimana pun juga ketika proses pendidikan berlangsung, dampaknya akan dirasakan bukan saja hanya untuk siswa itu sendiri, melainkan juga untuk masyarakat yang menerima dan memakai lulusannya. Oleh sebab itu, kemampuan untuk mendengar, melihat, dan memerthatikan tuntutan dan kebutuhan masyarakat sangat perlu ditingkatkan. ${ }^{12}$ Penjelasan PP No. 19 Tahun 2005 disebutkan bahwa: "Kompetensi sosial, yaitu merupakan kemampuan pendidik sebagai bagian dari masyarakat untuk: (1) berkomunikasi lisan dan tulisan (2) menggunakan teknologi komunikasi dan informasi secara fungsional:

${ }^{9}$ Yusrizal, dkk., Evaluasi Kinerja Guru Fisika, Biologi Dan Kimia SMA yang Sudah Lulus Sertifikasi, Jurnal Penelitian dan Evaluasi Pendidikan Universitas Syiah Kuala, Tahun 15, Nomor 2, 2011, h.274, https://journal.uny.ac.id/index.php/jpep/article/viewFile/1097/1149, diakses 11-01-2020.

10 Iman Wahyudi, Panduan Uji Sertifikasi Guru Sertifikasi. (Jakarta: PT. Prestasi Pustakaraya, 2012), h. 19.

11 Jamil Suprahatiningrum. Guru Profesional. (Yogyakarta: Ar-Ruzz Media, 2014), h. 106.

\footnotetext{
12 Jamil Suprahatiningrum. Guru Profesional. (Yogyakarta: Ar-Ruzz Media, 2014), h.
} $110-112$. 


\section{Irfani}

ISSN 1907-0969 E ISSN 2442-8272

Volume 15 Nomor 1 Juni 2019

Halaman 98-121

http://journal.iaingorontalo.ac.id/index.php/ir

(3) bergaul secara efektif dengan peserta didik, sesama pendidik, tenaga kependidikan, orang tua/wali; (4) bergaul secara santun dengan masyarakat sekitar". ${ }^{13}$

\section{c. Kompetensi Profesional}

Kompetensi profesional merupakan kemampuan dalam penguasaan materi pembelajaran secara luas dan mendalam yang memungkinkannya membimbing peserta didik memenuhi standar kompetensi. Kompetensi profesional guru merupakan kompetensi yang menggambarkan kemampuan khusus yang sadar dan terarah kepada tujuan tertentu. ${ }^{14}$ Guru yang mempunyai kompetensi profesional harus mampu memilih dan memilah serta mengelompokkan materi pembelajaran serta mengelompokkan materi pembelajaran yang akan disampaikannya kepada siswa sesuai dengan jenisnya. Tanpa kompetensi tersebut, dapat dipastikan bahwa guru tersebut akan menghadapi berbagai kesulitan dalam membentu kompetensi siswa, bahkan akan gagal dalam melaksanakan pembelajaran. ${ }^{15}$

\section{d. Kompetensi Pedagogik}

Menurut Musfah kompetensi pedagogik adalah kemampuan dalam pengelolaan peserta didik yang meliputi (a) pemahaman wawasan atau landasan kependidikan; (b) pemahaman tentang peserta didik; (c) pengembangan kurikulum atau silabus; (d) perancangan pembelajaran; (e) pelaksanaan pembelajaran yang mendidik dan dialogis; (f) evaluasi hasil belajar; dan (g) pengembangan peserta didik untuk mengaktualisasikan berbagai potensi yang dimilikinya. $^{16}$

\section{PENGELOLAAN PEMBELAJARAN}

Pengelolaan adalah serangkaian kegiatan yang berkaitan dengan merencanakan, mengorganisasikan, memotivasi, mengendalikan, dan mengembangkan segala upaya di dalam mengatur dan mendayagunakan sumber daya manusia, sarana dan prasarana untuk mencapai tujuan organisasi. Agar bisa tercapai hasil yang optimal, maka segala sesuat perlu pengelolaan. ${ }^{17}$ Peranan guru sangat dominan dalam proses pembelajaran. Pencapaian tujuan pendidikan nasional dapat terwujud bila pembelajaran yang dilakukan oleh guru merupakan pembelajaran yang berkualitas. Istilah pembelajaran merupakan terjemahan dari bahasa Inggris, yaitu learning. Pembelajaran merupakan suatu upaya yang

13 Iman Wahyudi, Panduan Uji Sertifikasi Guru Sertifikasi. (Jakarta: PT. Prestasi Pustakaraya, 2012), h. 25

${ }^{14}$ Ibid., h. 23

${ }^{15}$ Jamil Suprahatiningrum. Guru Profesional.. h. 110-117.

16 Menurut Musfah, Peningkatan Kompetensi Guru melalui Pelatihan dan Sumber Belajar Teori dan Praktik. (Jakarta, Prenadamedia Group, 2015), h. 30

${ }^{17}$ Bermawi Munthe, Desain Pembelajaran, (Yogyakarta: Pustaka Insan Madani, 2009), hal. 55 


\section{Irfani}

ISSN 1907-0969 E ISSN 2442-8272

Volume 15 Nomor 1 Juni 2019

Halaman 98-121

http://journal.iaingorontalo.ac.id/index.php/ir

dilakukan dengan sengaja oleh pendidik untuk menyampaikan ilmu pengetahuan, mengorganisasi dan menciptakan sistem lingkungan dengan berbagai metode sehingga siswa dapat melakukan kegiatan belajar secara efektif dan efisien serta dengan hasil yang maksimal. ${ }^{18}$

Arikunto yang dikutip Alfian Erwinsyah mendefinisikan pengelolaan pembelajaran adalah suatu usaha yang dilakukan oleh guru dalam kegiatan pembelajaran atau orang yang membantunya dengan maksud agar tercapai kondisi optimal, sehingga dapat terlaksana kegiatan belajar seperti yang diharapkan. ${ }^{19}$ Menurut Daryanto pengelolaan pembelajaran merupakan proses pembelajaran utuh dan menyeluruh yang dimulai dari perencanaan, pelaksanaan, hingga evaluasi pembelajaran, termasuk evaluasi programnya dalam rangka mencapai tujuan pendidikan seperti yang telah ditentukan. Pengelolaan pembelajaran merupakan proses mengelola suatu sistem kegiatan belajar, sehingga proses pembelajaran dapat berlangsung secara efektif dan efisien, dan dapat memenuhi tujuan yang direncanakan sebelumnya. ${ }^{20}$

Tujuan utama pengelolaan pembelajaran adalah untuk menghemat waktu dan tenaga.Pengelolaan pembelajaran yang baik menolong menyediakan kondisi belajar yang menyenangkan dan prosedur yang efektif dalam menjalankan aktivitas secara ekonomis dan efisien. Raka Joni berpendapat bahwa pengeloaaan pembelajaran yang efektif merupakan prasyarat mutlak bagi terjadinya proses belajar mengajar yang efektif. ${ }^{21}$

Moh. Uzer Usman, menyatakan ada beberapa indikator kinerja guru dalam pengelolaan pembelajaran, yaitu:

a. Kemampuan merencanakan belajar mengajar. Kemampuan ini meliputi:

1) Menguasai garis-garis besar penyelenggaraan pendidikan

2) Menyesuaikan analisa materi pelajaran

3) Menyusun program semester

4) Menyusun program atau pembelajaran

b. Kemampuan melaksanakan kegiatan hasil belajar. Kemampuan ini meliputi:

1) Tahap pra instruksional

2) Tahap instruksional

${ }^{18}$ Sugihartono dkk Sugihartono, dkk.Psikologi Pendidikan Cet-1. (Yogyakarta: UNY Press. 2007), hal. 81

${ }^{19}$ Alfian Erwinsyah, Manajemen Pembelajaran dalam Kaitannya dengan Peningkatan Kualitas Guru, "Tadbir" Jurnal Manajemen Pendidikan Islam Volume 5 No. 1 Februari 2017, h. 73, file:///C:/Users/mackbookair/Downloads/517-Article\%20Text-1494-1-10-20181201.pdf, diakses 12-01-2020

${ }^{20}$ Daryanto, Media Pembelajaran, (Yogyakarta: Gava Media, 2010), h.167

21 Alfian Erwinsyah, Manajemen Pembelajaran dalam Kaitannya dengan Peningkatan Kualitas Guru, "Tadbir” Jurnal Manajemen Pendidikan Islam Volume 5 No. 1 Februari 2017, h. 74, file:///C:/Users/mackbookair/Downloads/517-Article\%20Text-1494-1-10-20181201.pdf, diakses 12-01-2020. 


\section{Irfani}

ISSN 1907-0969 E ISSN 2442-8272

Volume 15 Nomor 1 Juni 2019

Halaman 98-121

http://journal.iaingorontalo.ac.id/index.php/ir

3) Tahap evaluasi dan tindak lanjut

c. Kemampuan mengevaluasi. Kemampuan ini meliputi:

1) Evaluasi normatif

2) Evaluasi formatif

3) Laporan hasil evaluasi

4) Pelaksanaan program perbaikan dan pengayaan. ${ }^{22}$

Dalam Bab IV Pasal 19 ayat (1) Standar Nasional Pendidikan ditentukan bahwa proses pembelajaran pada satuan pendidikan diselenggarakan secara interaktif, inspiratif, menyenangkan, menantang, memotivasi peserta didik untuk berpartisipasi aktif, serta memberikan ruang yang cukup bagi prakarsa, kreativitas, dan kemandirian sesuai bakat, minat dan perkembangan fisik serta psikologis peserta didik. Dalam proses pembelajaran ditentukan pula agar pendidik memberikan keteladanan. ${ }^{23}$

Pengelolaan pembelajaran yang baik tidak hanya mengacu pada manajemen (perencanaan, pengelolaan, pengawasan serta evaluasi) saja. Manajemen pembelajaran juga harus memperhatikan potensi peserta didik serta mampu mengarahkan peserta didik untuk mengembangkan kemampuan untuk mengetahui, memahami, melakukan sesuatu, hidup dalam kebersamaan dan mengaktualisasikan diri. Dengan demikian manajemen pembelajaran perlu: 1) berpusat pada peserta didik; 2) mengembangkan kreatifitas peserta didik; 3) menciptakan kondisi yang menyenangkan dan menantang; 4) bermuatan, nilai, etika, estetika, logika, dan kinestetika, dan 5) menyediakan pengalaman belajar yang beragam. ${ }^{24}$

\section{METODE PENELITIAN}

Penelitian yang dilakukan ini masuk dalam jenis penelitian kualitatif, yang sumber datanya didapatkan dari observasi, wawancara dan dokumentasi. Penelitian ini berlangsung di Sekolah Menengah Pertama Negeri Sinombayuga Bolaang Mongondow Selatan.

\section{HASIL PENELITIAN DAN PEMBAHASAN}

Berdasarkan hasil wawancara dengan guru yang tersertifikasi di SMP Negeri Sinombayuga Kecamatan Posigadan Kabupaten Bolaang Mongondow Selatan menyatakan bahwa sebagai guru yang telah memiliki sertifikasi, disini kami harus memiliki kemampuan dalam berbagai hal terkait dengan pengelolaan pembelajaran, serta harus mampu menguasai keilmuan sesuai dengan bidang yang

${ }^{22}$ Moh.Uzer Usman, Menjadi Guru profesional, h. 10.

${ }^{23}$ Yanty K. Manoppo, Analisis penerapan standar proses pembelajaran Pendidikan Agama Islam di SMP Negeri 2 Kota Gorontalo, Jurnal Manajemen Pendidikan Islam Volume 2 No. 2 Agustus 2014, h. 188, https://adoc.tips/analisis-penerapan-standar-proses-pembelajaranpendidikan-ag.html, diakses 16-01-2020

${ }^{24}$ Abdul Majid, Perencanaan Pembelajaran (Mengembangkan Standar Kompetensi Guru), (Bandung: Remaja Rosdakarya), h.. 24. 


\section{Irfani}

ISSN 1907-0969 E ISSN 2442-8272

Volume 15 Nomor 1 Juni 2019

Halaman 98-121

http://journal.iaingorontalo.ac.id/index.php/ir

kami ampu secara teoritis maupun prakteknya, salah satunya adalah sebagai guru profesional saya akan menyiapkan hal- hal yang sangat sibutuhkan dalam proses belajar mengajar, salah satunya saya haru membuat dan membawa RPP dalam mengajar, namanya seorang guru yang sudah profesional, guru yang sudah bersertifikasi, pasti kita menyiapkan RPP. Sebelum kita sertifikasi pun harus mennyiapkan RPP, karena RPP itu adalah tugas pokok kita, karena kita yang sudah profesional, jauh dari RPP juga disiapkan, lengkapkan administrasi kita baru bisa masuk kedalam kelas. Begitu juga dengan silabus. Harus buat silabus lalu membuat RPP. ${ }^{25}$

Hal senada juga disampaikan oleh salah seorang guru yang telah disertifikasi bahwa RPP wajib disiapkan dalam mengajar, RPP merupakan pedoman guru untuk mengajar, biasanya RPP saya buat awal semester, lalu saya kembangkan lagi pertiap pertemuan tatap muka dengan siswa sesuai dengan kelas dan materinya. Begitu juga dengan silabus, sebelum membuat RPP pastinya saya membuat pedoman terlebih dahulu, jika tidak membuat silabus bagaimana saya akan menyusun RPP saya. ${ }^{26}$

Berdasarkan dari wawancara diatas, guru wajib menyiapkan silabus dan RPP dalam proses pembelajaran, karena silabus dan RPP merupakan hal pokok bagi seorang guru, jika seorang guru tidak menyiapkan silabus dan RPP, maka proses pembelajaran pun tidak terlaksana dengan baik. Ketika seorang guru memberi ajaran kepada peserta didik, tentunya seorang guru juga akan menggunakan media pembelajaran dalam proses belajar mengajar berlangsung.

Menurut Kepala Sekolah bahwa di era digital sekarang media pembelajaran berbagai macam ragam yang dapat saya gunakan untuk menunjang kegiatan proses pembelajaran sesuai materi yang diajarkan, seperti infocus dan alat peraga, apalagi sebagai guru yang bersertifikasi, guru-guru diharapkan mampu menciptakan suasana yang sangat nyaman dan siswa betah dalam mengikuti pembelajaran, karena di era digital seperti sekarang metode ceramah saja tidak mampu meningkatkan kwalitas pembelajaran tersebut. maka oleh itu betapa pentingnya media pembelajaran untuk menunjang tingkat keberhasilan belajar mengajar. $^{27}$

Begitu juga dengan temuan peneliti yang disampaikan oleh Ratmin Hambali bahwa media pembelajaran sangat penting sekali dan selalu saya gunakan dalam pembelajaran, kalau tidak ada media pembelajaran, siswa-siswa tidak berminat untuk mengikuti pembelajaran, karena tidak bisa ceramah saja, 2019.

${ }^{25}$ Kristian Ointu, Guru di SMP N Sinombayuga Kecamatan Posigadan, Wawancara,

${ }^{26}$ Fitriana Lemba, Guru di SMP N Sinombayuga Kecamatan Posigadan, Wawancara, 2019.

27 Iam Kasiaradja, Kepala sekolah di SMP N Sinombayuga Kecamatan Posigadan, Wawancara, 2019. 


\section{Irfani}

ISSN 1907-0969 E ISSN 2442-8272

Volume 15 Nomor 1 Juni 2019

Halaman 98-121

http://journal.iaingorontalo.ac.id/index.php/ir

siswa-siswa tidak akan beminat dan kreatif dalam belajar apabila tidak menggunakan media pembelajaran. ${ }^{28}$

Berdasarkan dari wawancara diatas mengenai media pembelajaran yang disampaikan dari kepala sekolah SMP Negeri Sinombayuga Kecamatan Posigadan Kabupaten Bolaang Mongondow Selatan, bahwa media pembelajaran disekolah itu sangat diperlukan, karena media pembelajaran tersebut adalah salah satu upaya dalam meningkatkan proses pembelajaran berlangsung. Selain media pembelajaran, tentu nya guru juga akan menggunakan strategi agar ketika guru menggunakan media pembelajaran, siswa dapat kondusif mengikuti proses pembelajaran berlangsung.

Disamping media pembelajaran guru yang sudah tersertifikasi juga harus mampu menunjukan sikap yang mendukung dan dalam proses belajar mengajar, dan mampu menjalin hubungan yang baik dengan siswa selama pembelajaran berlangsung. Sebagaimana yang disampaikan oleh Kepala Sekolah bahwa sebagai kepala sekolah saya selalu meminta Guru harus mampu melakukan komunikasi yang baik terhadap siswa, baik dalam hal melibatkan siswa dalam proses pembelajaran. Sebab komunikasi guru dan siswa sangat penting terbangun dengan baik, begitu juga antara siswa dengan siswa seorang guru juga harus mampu mengarahkan agar terjalin komunikasi yang baik pula, disamping komunikasi yang harus melibatkan siswa dalam materi pembelajaran. ataupun komunikasi diluar jam pembelajaran selalu diharapkan berjalan dengan baik dan kondusif. Namun sepertinya hal tersebut belum bisa terlaksana dengan baik, Faktor lingkunganlah yang menyebabkan kondisi ini masih sulit untuk di rubah oleh seorang guru. ${ }^{29}$

Begitu juga dengan hasil wawancara yang disampaikan oleh Ibu Fitriana lemba, yang mengatakan bahwa disamping seorang seorang guru harus mampu menjalin hubungan yang baik dengan siswa, seorang guru dituntut juga harus berbuat adil dalam mengajar ketika proses pembelajaran, oleh sebab itu guru harus stabil kepada siswa. Supaya kondusif nya itu tergantung bagaimana guru menguasai kelas, karena jika guru tidak pandai menguasai kelas, tentunya siswa tidak kondusif dalam belajar, guru harus bisa menguasai kelas, dan mengetahui kegiatan-kegiatan siswa dan kita harus mengetahui sifat-sifat siswa, apa yang mereka minat untuk masuk ke proses pembelajaran. ${ }^{30}$

Untuk mengukur implementasi keberhasilan seorang guru dalam mengelola pembelajaran harus adanya evaluasi terhadap keberhasilan suatu

${ }^{28}$ Ratmin Hambali, Guru di SMP N Sinombayuga Kecamatan Posigadan, Wawancara, 2019.

${ }^{29}$ Iam Kasiaradja, Kepala sekolah di SMP N Sinombayuga Kecamatan Posigadan, Wawancara, 2019. 2019.

${ }^{30}$ Fitriana Lemba, Guru di SMP N Sinombayuga Kecamatan Posigadan, Wawancara, 


\section{Irfani}

ISSN 1907-0969 E ISSN 2442-8272

Volume 15 Nomor 1 Juni 2019

Halaman 98-121

http://journal.iaingorontalo.ac.id/index.php/ir

pembelajaran sebagaimana hasil wawancara bahwa sebagai guru yang profesional saya selalu membuat bahan evaluasi untuk siswa, karena untuk mengevaluasi seberapa paham murid-murid dengan materi yang saya ajarkan biasanya saya menggunakan kuis setiap akhir pembelajaran sebelum penutupan pembelajaran saya langsungkan. Agar saya dapat mengetahui seberapa jauh murid-murid dapat menangkap dan memahami materi yang baru saya ajarkan. ${ }^{31}$

Adapun format PKG yang diperoleh penulis di lapangan, terdapat komponen-komponen PKG dalam pengelolaan pembelajaran, sebagai berikut :

1. Kompetensi Pedagogik dan Profesional dalam pengelolaan pembelajaran Indikator penilaian Kompetensi Pedagogik dan Profesional dapat di lihat pada format berikut ini :

a. Format Penilaian Administrasi Perencanaan Pembelajaran

Tabel 1. Format Supervisi Administrasi Perencanaan Pembelajaran

\begin{tabular}{|c|c|c|c|c|c|c|c|c|}
\hline \multirow{2}{*}{ No } & \multirow[b]{2}{*}{$\begin{array}{c}\text { Komponen Administrasi } \\
\text { Pembelajaran }\end{array}$} & \multicolumn{2}{|c|}{ Kondisi } & \multicolumn{4}{|c|}{ Skor Nilai } & \multirow{2}{*}{$\begin{array}{l}\text { Keterangan } \\
\text { Kesesuaian }\end{array}$} \\
\hline & & $\mathrm{Ya}$ & $\begin{array}{c}\text { Tida } \\
\mathrm{k}\end{array}$ & 4 & 3 & 2 & 1 & \\
\hline 1. & Kalender Pendidikan & & & & & & & \multirow{11}{*}{$\begin{array}{l}\text { 4= Baik } \\
\text { Sekali } \\
3=\text { Baik } \\
2=\text { Cukup } \\
\text { 1= Kurang }\end{array}$} \\
\hline 2. & Program Tahunan & & & & & & & \\
\hline 3. & Program Semester & & & & & & & \\
\hline 4. & Rincian Pekan Efektif & & & & & & & \\
\hline 5. & Analisis KI, KD, SKL & & & & & & & \\
\hline 6. & Silabus \& RPP & & & & & & & \\
\hline 7. & KKM & & & & & & & \\
\hline 8. & Jadwal Tatap Muka & & & & & & & \\
\hline 9. & Agenda Harian/Jurnal & & & & & & & \\
\hline 10. & Absensi Siswa & & & & & & & \\
\hline \multicolumn{4}{|c|}{ Jumlah Skor } & & & & & \\
\hline
\end{tabular}

Sumber data : Dokumen PKG SMP Negeri Sinombayuga, 07-01-2020.

Berdasarkan tabel di atas dapat diketahui bahwa terdapat 10 komponen penilaian kinerja guru terhadap administrasi pembelajaran, yang terdiri dari : 1) kalender pendidikan; 2) program tahunan; 3) program semester; 4) Rincian Pekan Efektif; 5) Analisis KI, KD, SKL; 6) Silabus \&RPP; 7) KKM; 8) Jadwal tatap muka; 9) Agenda Harian/Jurnal;dan 10) Absensi Siswa.

\section{b. Format Telaah RPP}

\footnotetext{
${ }^{31}$ Sartin Ney, Guru di SMP N Sinombayuga Kecamatan Posigadan, Wawancara, 2019.
} 


\section{Irfani}

ISSN 1907-0969 E ISSN 2442-8272

Volume 15 Nomor 1 Juni 2019

Halaman 98-121

http://journal.iaingorontalo.ac.id/index.php/ir

Tabel 2. Format Telaah Rencana Pelaksanaan Pembelajaran (RPP)

\begin{tabular}{|c|c|c|c|c|c|}
\hline \multirow[t]{2}{*}{ No. } & \multirow{2}{*}{$\begin{array}{c}\text { Komponen Rencana Pelaksanaan } \\
\text { Pembelajaran }\end{array}$} & \multicolumn{3}{|c|}{ Hasil Telaah \& Skor } & \multirow{2}{*}{$\begin{array}{l}\text { Catatan } \\
\text { Revisi }\end{array}$} \\
\hline & & 1 & 2 & 3 & \\
\hline A. & Identitas Mata Pelajaran & $\begin{array}{l}\text { Tidak } \\
\text { Ada }\end{array}$ & $\begin{array}{c}\text { Kurang } \\
\text { Lengkap }\end{array}$ & $\begin{array}{c}\text { Sudah } \\
\text { Lengkap }\end{array}$ & \\
\hline 1. & $\begin{array}{l}\text { Terdapat : Satuan Pendidikan, Kelas, } \\
\text { Semester, Mata pelajaran, jumlah } \\
\text { pertemuan. }\end{array}$ & & & & \\
\hline B. & $\begin{array}{l}\text { Kompetensi Inti dan Kompetensi } \\
\text { Dasar }\end{array}$ & $\begin{array}{l}\text { Tidak } \\
\text { Ada }\end{array}$ & $\begin{array}{l}\text { Kurang } \\
\text { Lengkap }\end{array}$ & $\begin{array}{c}\text { Sudah } \\
\text { Lengkap }\end{array}$ & \\
\hline 1. & Kompetensi Inti & & & & \\
\hline 2. & Kompetensi Dasar & & & & \\
\hline $\mathrm{C}$. & Perumusan Indikator & $\begin{array}{l}\text { Tidak } \\
\text { Sesuai }\end{array}$ & $\begin{array}{c}\text { Sesuai } \\
\text { Sebagian }\end{array}$ & $\begin{array}{c}\text { Sesuai } \\
\text { Seluruhnya }\end{array}$ & \\
\hline 1. & Kesesuaian dengan KD. & & & & \\
\hline 2. & $\begin{array}{l}\text { Kesesuaian penggunaan kata kerja } \\
\text { operasional dengan kompetensi yang } \\
\text { diukur }\end{array}$ & & & & \\
\hline 3. & $\begin{array}{l}\text { Kesesuaian rumusan dengan aspek } \\
\text { Pengetahuan }\end{array}$ & & & & \\
\hline 4. & $\begin{array}{l}\text { Kesesuaian rumusan dengan aspek } \\
\text { Keterampilan }\end{array}$ & & & & \\
\hline D. & Perumusan Tujuan Pembelajaran & $\begin{array}{l}\text { Tidak } \\
\text { Sesuai }\end{array}$ & $\begin{array}{c}\text { Sesuai } \\
\text { Sebagian }\end{array}$ & $\begin{array}{c}\text { Sesuai } \\
\text { Seluruhnya }\end{array}$ & \\
\hline 1. & Kesesuaian dengan KD. & & & & \\
\hline 2. & Kesesuaian dengan Indikator & & & & \\
\hline 3. & $\begin{array}{l}\text { Kesesuaian perumusan dengan aspek } \\
\text { Audience, Behaviour, Condition dan } \\
\text { Degree }\end{array}$ & & & & \\
\hline E. & Pemilihan Materi Ajar & $\begin{array}{l}\text { Tidak } \\
\text { Sesuai }\end{array}$ & $\begin{array}{c}\text { Sesuai } \\
\text { Sebagian }\end{array}$ & $\begin{array}{c}\text { Sesuai } \\
\text { Seluruhnya }\end{array}$ & \\
\hline 1. & Kesesuaian dengan KD. & & & & \\
\hline 2. & $\begin{array}{l}\text { Kesesuaian dengan Tujuan } \\
\text { Pembelajaran }\end{array}$ & & & & \\
\hline 3. & $\begin{array}{l}\text { Kesesuaian dengan karakteristik } \\
\text { peserta didik }\end{array}$ & & & & \\
\hline 4. & Keruntutan Uraian Materi ajar & & & & \\
\hline $\mathrm{F}$. & Pemilihan Sumber Belajar & $\begin{array}{l}\text { Tidak } \\
\text { Sesuai }\end{array}$ & $\begin{array}{c}\text { Sesuai } \\
\text { Sebagian }\end{array}$ & $\begin{array}{c}\text { Sesuai } \\
\text { Seluruhnya }\end{array}$ & \\
\hline
\end{tabular}




\section{Irfani}

ISSN 1907-0969 E ISSN 2442-8272

Volume 15 Nomor 1 Juni 2019

Halaman 98-121

http://journal.iaingorontalo.ac.id/index.php/ir

\begin{tabular}{|c|c|c|c|c|c|}
\hline \multirow[t]{2}{*}{ No. } & \multirow{2}{*}{$\begin{array}{c}\text { Komponen Rencana Pelaksanaan } \\
\text { Pembelajaran }\end{array}$} & \multicolumn{3}{|c|}{ Hasil Telaah \& Skor } & \multirow{2}{*}{$\begin{array}{l}\text { Catatan } \\
\text { Revisi }\end{array}$} \\
\hline & & 1 & 2 & 3 & \\
\hline 1. & $\begin{array}{l}\text { Kesesuaian dengan Tujuan } \\
\text { Pembelajaran. }\end{array}$ & & & & \\
\hline 2. & $\begin{array}{l}\text { Kesesuaian dengan materi } \\
\text { pembelajaran }\end{array}$ & & & & \\
\hline 3. & $\begin{array}{l}\text { Kesesuaian dengan pendekatan } \\
\text { Saintifik }\end{array}$ & & & & \\
\hline 4. & $\begin{array}{l}\text { Kesesuaian dengan karakteristik } \\
\text { peserta didik }\end{array}$ & & & & \\
\hline G. & Pemilihan Media Pembelajaran & $\begin{array}{l}\text { Tidak } \\
\text { Sesuai }\end{array}$ & $\begin{array}{c}\text { Sesuai } \\
\text { Sebagian }\end{array}$ & $\begin{array}{c}\text { Sesuai } \\
\text { Seluruhnya }\end{array}$ & \\
\hline 1. & $\begin{array}{l}\text { Kesesuaian dengan Tujuan } \\
\text { Pembelajaran. }\end{array}$ & & & & \\
\hline 2. & $\begin{array}{l}\text { Kesesuaian dengan materi } \\
\text { pembelajaran }\end{array}$ & & & & \\
\hline 3. & $\begin{array}{l}\text { Kesesuaian dengan pendekatan } \\
\text { Saintifik }\end{array}$ & & & & \\
\hline 4. & $\begin{array}{l}\text { Kesesuaian dengan karakteristik } \\
\text { peserta didik }\end{array}$ & & & & \\
\hline H. & Model Pembelajaran & $\begin{array}{l}\text { Tidak } \\
\text { Sesuai }\end{array}$ & $\begin{array}{c}\text { Sesuai } \\
\text { Sebagian }\end{array}$ & $\begin{array}{c}\text { Sesuai } \\
\text { Seluruhnya }\end{array}$ & \\
\hline 1. & $\begin{array}{l}\text { Kesesuaian dengan Tujuan } \\
\text { Pembelajaran. }\end{array}$ & & & & \\
\hline 2. & $\begin{array}{l}\text { Kesesuaian dengan karakteristik } \\
\text { materi }\end{array}$ & & & & \\
\hline I. & Metode Pembelajaran & $\begin{array}{l}\text { Tidak } \\
\text { Sesuai }\end{array}$ & $\begin{array}{c}\text { Sesuai } \\
\text { Sebagian }\end{array}$ & $\begin{array}{c}\text { Sesuai } \\
\text { Seluruhnya }\end{array}$ & \\
\hline 1. & $\begin{array}{l}\text { Kesesuaian dengan Tujuan } \\
\text { Pembelajaran. }\end{array}$ & & & & \\
\hline 2. & $\begin{array}{l}\text { Kesesuaian dengan karakteristik } \\
\text { materi }\end{array}$ & & & & \\
\hline 3. & $\begin{array}{l}\text { Kesesuaian dengan karakteristik } \\
\text { peserta didik }\end{array}$ & & & & \\
\hline $\mathrm{J}$. & Skenario Pembelajaran & $\begin{array}{l}\text { Tidak } \\
\text { Sesuai }\end{array}$ & $\begin{array}{c}\text { Sesuai } \\
\text { Sebagian }\end{array}$ & $\begin{array}{c}\text { Sesuai } \\
\text { Seluruhnya }\end{array}$ & \\
\hline 1. & $\begin{array}{l}\text { Menampilkan kegiatan Pendahuluan, } \\
\text { Inti dan Penutup dengan Jelas. }\end{array}$ & & & & \\
\hline 2. & Kesesuaian dengan pendekatan & & & & \\
\hline
\end{tabular}




\section{Irfani}

ISSN 1907-0969 E ISSN 2442-8272

Volume 15 Nomor 1 Juni 2019

Halaman 98-121

http://journal.iaingorontalo.ac.id/index.php/ir

\begin{tabular}{|c|c|c|c|c|c|}
\hline \multirow[t]{2}{*}{ No. } & \multirow{2}{*}{$\begin{array}{c}\text { Komponen Rencana Pelaksanaan } \\
\text { Pembelajaran }\end{array}$} & \multicolumn{3}{|c|}{ Hasil Telaah \& Skor } & \multirow{2}{*}{$\begin{array}{l}\text { Catatan } \\
\text { Revisi }\end{array}$} \\
\hline & & 1 & 2 & 3 & \\
\hline & $\begin{array}{l}\text { Saintifik (mengamati, menanya, } \\
\text { mengumpulkan informasi, } \\
\text { mengasosiasikan informasi, } \\
\text { mengkomunikasikan) }\end{array}$ & & & & \\
\hline 3. & $\begin{array}{l}\text { Kesesuaian dengan metode } \\
\text { pembelajaran }\end{array}$ & & & & \\
\hline 4. & $\begin{array}{l}\text { Kesesuaian kegiatan dengan } \\
\text { sistematika/keruntutan materi }\end{array}$ & & & & \\
\hline 5. & $\begin{array}{l}\text { Kesesuaian alokasi waktu kegiatan } \\
\text { Pendahuluan, Inti dan Penutup dengan } \\
\text { cakupan materi }\end{array}$ & & & & \\
\hline K. & Rancangan Penilaian Pembelajaran & $\begin{array}{l}\text { Tidak } \\
\text { Sesuai }\end{array}$ & $\begin{array}{c}\text { Sesuai } \\
\text { Sebagian }\end{array}$ & $\begin{array}{c}\text { Sesuai } \\
\text { Seluruhnya }\end{array}$ & \\
\hline 1. & $\begin{array}{l}\text { Kesesuaian bentuk, tehnik dan } \\
\text { instrumen dengan Indikator } \\
\text { Pencapaian Kompetensi }\end{array}$ & & & & \\
\hline 2. & $\begin{array}{l}\text { Kesesuaian antara bentuk, tehnik dan } \\
\text { instrumen penilaian sikap }\end{array}$ & & & & \\
\hline 3. & $\begin{array}{l}\text { Kesesuaian antara bentuk, tehnik dan } \\
\text { instrumen penilaian pengetahuan }\end{array}$ & & & & \\
\hline 4. & $\begin{array}{l}\text { Kesesuaian antara bentuk, tehnik dan } \\
\text { instrumen penilaian keterampilan }\end{array}$ & & & & \\
\hline
\end{tabular}

Sumber data : Dokumen PKG SMP Negeri Sinombayuga, 07-01-2020

Dari uraian tabel di atas jelaslah bahwa terdapat 11 komponen Utama telaah Rencana Pelaksanaan Pembelajaran (RPP), terdiri dari : 1) Identitas Mata Pelajaran dengan 1 indikator yang dinilai; 2) Kompetensi Inti dan Kompetensi Dasar dengan 2 indikator yang dinilai; 3) Perumusan Indikator dengan 4 indikator yang dinilai; 4) Perumusan Tujuan Pembelajaran dengan 3 indikator yang dinilai; 5) Pemilihan Materi Ajar dengan 4 indikator yang dinilai; 6) Pemilihan Sumber Belajar dengan 4 indikator yang dinilai; 7) Pemilihan Media Pembelajaran dengan 4 indikator yang dinilai; 8) Model Pembelajaran dengan 2 indikator yang dinilai; 9) Metode Pembelajaran dengan 3 indikator yang dinilai; 10) Skenario Pembelajaran dengan 5 indikator yang dinilai; dan 11) Rancangan Penilaian Pembelajaran dengan 4 indikator yang dinilai. Total keseluruhan komponen yang dinilai pada telaah Rencana Pelaksanaan Pembelajaran (RPP) adalah 36 Indikator. 


\section{Irfani}

ISSN 1907-0969 E ISSN 2442-8272

Volume 15 Nomor 1 Juni 2019

Halaman 98-121

http://journal.iaingorontalo.ac.id/index.php/ir

c. Format Pengamatan Pelaksanaan Pembelajaran

Tabel 3. Format Pengamatan Pelaksanaan Pembelajaran

\begin{tabular}{|c|c|c|c|c|c|}
\hline \multicolumn{2}{|c|}{ Aspek yang diamati } & $\mathbf{Y a}$ & Tidak & Catatan & Perbaikan \\
\hline \multicolumn{6}{|c|}{ KEGIATAN PENDAHULUAN } \\
\hline \multicolumn{6}{|c|}{ Apersepsi dan Motivasi } \\
\hline 1. & $\begin{array}{l}\text { Menyiapkan fisik dan psikis peserta didik } \\
\text { dengan menyapa dan memberi salam }\end{array}$ & & & & \\
\hline 2. & $\begin{array}{l}\text { Mengaitkan materi dengan materi } \\
\text { sebelumnya }\end{array}$ & & & & \\
\hline 3. & Mengajukan pertanyaan untuk memotivasi & & & & \\
\hline 4. & $\begin{array}{l}\text { Mendemonstrasikan sesuatu yang terkait } \\
\text { dengan materi pembelajaran }\end{array}$ & & & & \\
\hline 5. & $\begin{array}{l}\text { Menyampaikan manfaat materi } \\
\text { pembelajaran }\end{array}$ & & & & \\
\hline \multicolumn{2}{|c|}{$\begin{array}{l}\text { Penyampaian Kompetensi dan Rencana } \\
\text { Kegiatan }\end{array}$} & & & & \\
\hline 1. & $\begin{array}{l}\text { Menyampaikan kompetensi yang akan } \\
\text { dicapai peserta didik }\end{array}$ & & & & \\
\hline 2. & $\begin{array}{l}\text { Menyampaikan rencana kegiatan misalnya } \\
\text { individual, kerja kelompok dan melakukan } \\
\text { observasi. }\end{array}$ & & & & \\
\hline \multicolumn{6}{|c|}{ KEGIATAN INTI } \\
\hline \multicolumn{6}{|c|}{ Penguasaan Materi Pembelajaran } \\
\hline 1. & $\begin{array}{l}\text { Kemampuan menyesuaikan materi dengan } \\
\text { tujuan pembelajaran }\end{array}$ & & & & \\
\hline 2. & $\begin{array}{l}\text { Kemampuan mengkaitkan materi dengan } \\
\text { pengetahuan lain yang relevan, } \\
\text { perkembangan IPTEK dan kehidupan nyata }\end{array}$ & & & & \\
\hline 3. & $\begin{array}{l}\text { Menyajikan pembahasan materi dengan } \\
\text { tepat }\end{array}$ & & & & \\
\hline 4. & $\begin{array}{l}\text { Menyajikan materi secara sistematis } \\
\text { (mudah ke sulit, dari konkrit ke abstrak) }\end{array}$ & & & & \\
\hline \multicolumn{2}{|c|}{$\begin{array}{l}\text { Penerapan Strategi Pembelajaran yang } \\
\text { mendidik }\end{array}$} & & & & \\
\hline 1. & $\begin{array}{l}\text { Melaksanakan pembelajaran sesuai dengan } \\
\text { kompetensi yang dicapai }\end{array}$ & & & & \\
\hline 2. & Melaksanakan pembelajaran secara runtut & & & & \\
\hline 3. & Menguasai kelas & & & & \\
\hline 4. & Melaksanakan pembelajaran yang & & & & \\
\hline
\end{tabular}




\section{Irfani}

ISSN 1907-0969 E ISSN 2442-8272

Volume 15 Nomor 1 Juni 2019

Halaman 98-121

http://journal.iaingorontalo.ac.id/index.php/ir

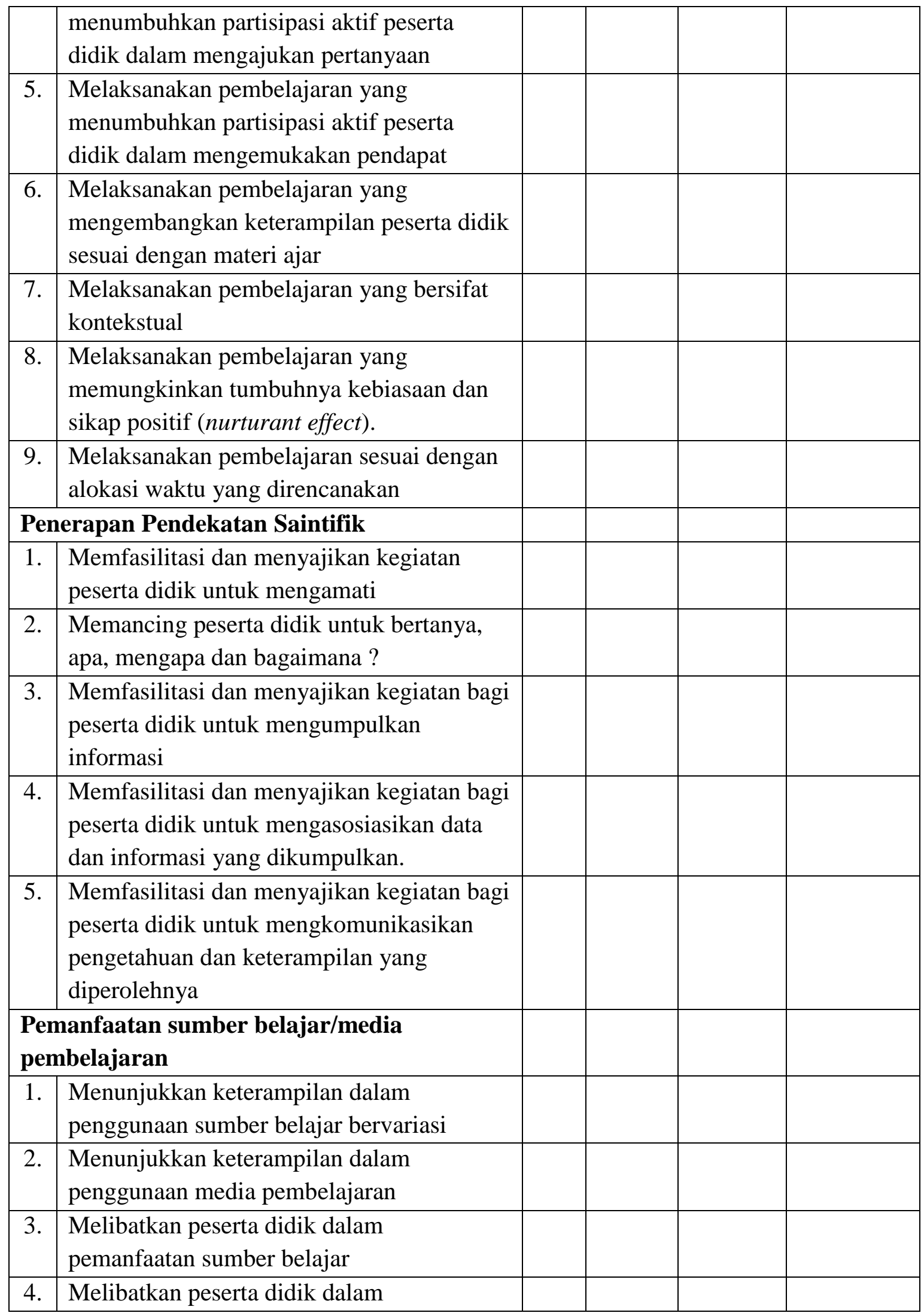




\section{Irfani}

ISSN 1907-0969 E ISSN 2442-8272

Volume 15 Nomor 1 Juni 2019

Halaman 98-121

http://journal.iaingorontalo.ac.id/index.php/ir

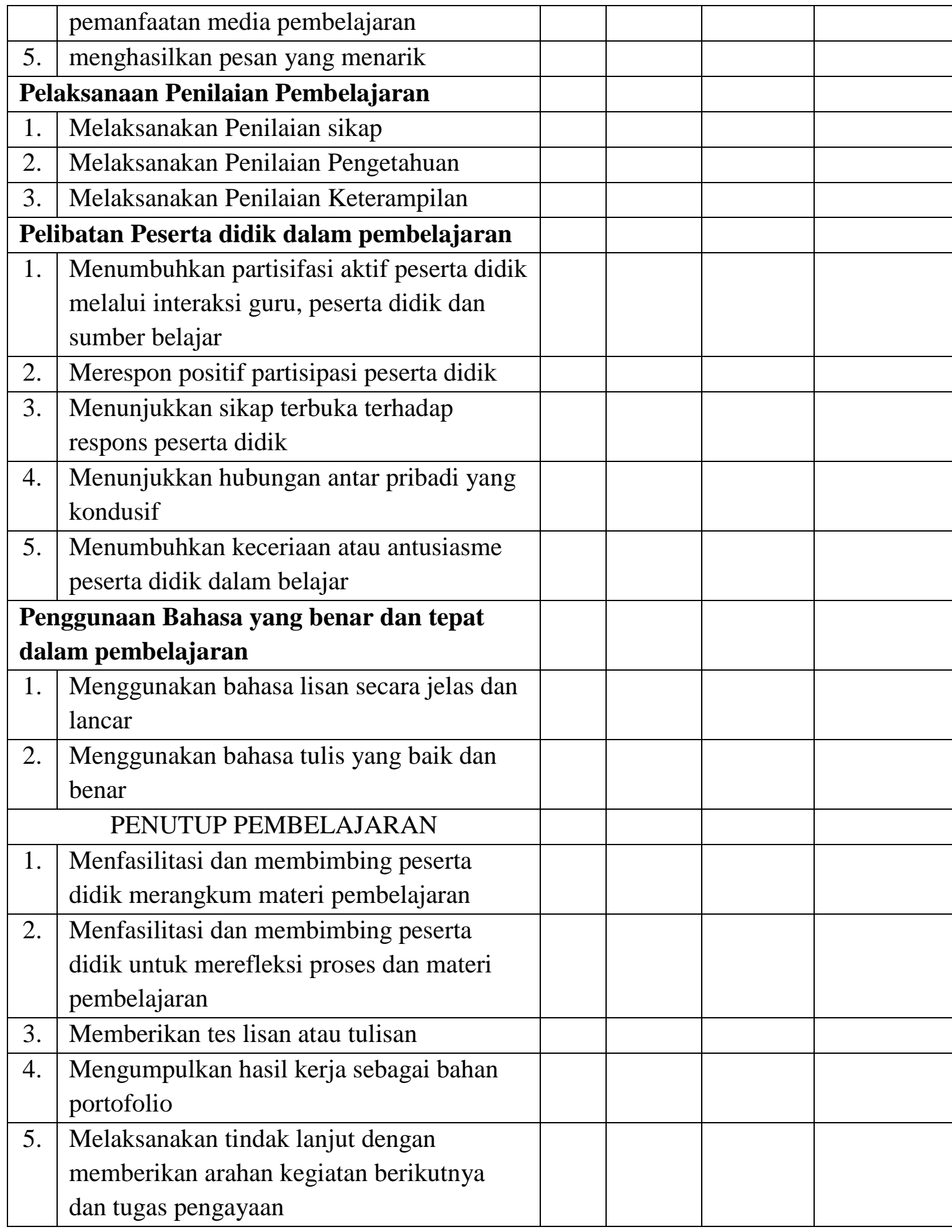

Sumber data : Dokumen PKG SMP Negeri Sinombayuga, 07-01-2020 


\section{Irfani}

ISSN 1907-0969 E ISSN 2442-8272

Volume 15 Nomor 1 Juni 2019

Halaman 98-121

http://journal.iaingorontalo.ac.id/index.php/ir

Format pengamatan Proses Pelaksanaan Pembelajaran sesuai tabel di atas terdapat 3 komponen Utama, yaitu : 1) Kegiatan pendahuluan terdapat 7 aspek yang diamati; 2) Kegiatan Inti terdapat 33 aspek yang diamati; dan 3) Penutup pembelajaran terdapat 5 aspek yang diamati. Jadi keseluruhan aspek yang diamati berjumlah 45 indikator.

d. Instrumen Penilaian dalam Pembelajaran

Tabel 4. Format Instrumen Penilaian dalam Pembelajaran

\begin{tabular}{|c|c|c|c|c|c|c|c|}
\hline \multirow{2}{*}{ No } & \multirow[b]{2}{*}{$\begin{array}{c}\text { Komponen Administrasi Penilaian } \\
\text { Pembelajaran }\end{array}$} & \multicolumn{2}{|c|}{ Kondisi } & \multicolumn{4}{|c|}{ Skor Nilai } \\
\hline & & $\mathrm{Ya}$ & $\begin{array}{c}\text { Tida } \\
\text { k }\end{array}$ & 4 & 3 & 2 & 1 \\
\hline 1. & Buku/Daftar Nilai & & & & & & \\
\hline 2. & $\begin{array}{l}\text { Penilaian Pengetahuan } \\
\quad>\text { Ulangan Harian } \\
>\text { Ulangan Tengah Semester } \\
>\text { Ulangan Akhir Semester } \\
>\text { Penugasan }\end{array}$ & & & & & & \\
\hline 3. & $\begin{array}{l}\text { Penilaian Keterampilan } \\
>\text { Praktek/Kinerja } \\
>\text { Portofolio } \\
>\text { Proyek }\end{array}$ & & & & & & \\
\hline 4. & $\begin{array}{l}\text { Penilaian Sikap } \\
\quad>\text { Observasi } \\
>\text { Penilaian Diri } \\
>\text { Penilaian Antar Teman } \\
>\text { Jurnal }\end{array}$ & & & & & & \\
\hline 5. & Analisis Ulangan Harian & & & & & & \\
\hline 6. & $\begin{array}{l}\text { Program/Pelaksanaan Remedial/ } \\
\text { Pengayaan }\end{array}$ & & & & & & \\
\hline 7. & Rancangan Penilaian & & & & & & \\
\hline 8. & Bank Soal & & & & & & \\
\hline & Jumlah Skor & & & & & & \\
\hline & NILAI/KATEGORI & & & & & & \\
\hline
\end{tabular}

Sumber data : Dokumen PKG SMP Negeri Sinombayuga, 07-01-2020.

Memperhatikan tabel di atas terdapat 8 komponen Penilaian Pembelajaran yang terdiri dari: 1) Buku/daftar nilai; 2) Penilaian sikap; 3) Penilaian pengetahuan; 4) Penilaian keterampilan; 5) Analisis Ulangan Harian; 6) program/pelaksanaan remedial/pengayaan; 7) rancangan penilaian; dan 8) bank soal. Kepala SMP Negeri Sinombayuga mengemukakan bahwa PKG tersertifikasi 


\section{Irfani}

ISSN 1907-0969 E ISSN 2442-8272

Volume 15 Nomor 1 Juni 2019

Halaman 98-121

http://journal.iaingorontalo.ac.id/index.php/ir

dinilai oleh Tim PKG pada setiap semester (Ganjil \& Genap), karena setiap pengurusan tunjangan sertifikasi setiap guru harus melampurkan hasil Penilaian Kinerja Guru. ${ }^{32}$

Berdasarkan dokumen PKG di SMP Negeri Sinombayuga, hasil Penilaian Kinerja Guru tersertifikasi untuk Semester Ganjil Tahun Pelajaran 2019/2020, sebagai berikut :

Tabel 5. Hasil PKG Tersertifikasi Kompetensi Pedagogik \& Profesional

\begin{tabular}{|c|c|c|c|c|c|c|}
\hline \multirow{2}{*}{ No. } & \multirow{2}{*}{ Nama Guru } & \multicolumn{4}{|c|}{ Komponen Penilaian } & \multirow{2}{*}{ Rata2 } \\
\hline & & 1 & 2 & 3 & 4 & \\
\hline 1. & Kristian Ointu, S.Pd. & 95 & 89.56 & 91 & 85.71 & 89.32 \\
\hline 2. & Harmus Pakaya & 90 & 86.95 & 86.67 & 83.92 & 86.88 \\
\hline 3. & Fitriana Lemba, S.Pd. & 92.50 & 90.43 & 88.89 & 87.50 & 89.83 \\
\hline & Rata-Rata & 92.50 & 88.98 & 88.85 & 85.71 & 88.68 \\
\hline
\end{tabular}

Sumber data : Dokumen PKG SMP Negeri Sinombayuga, 07-01-2020.

Keterangan Komponen Penilaian :

a Hasil Penilaian administrasi Perencanaan pembelajaran

b Hasil Telaah RPP

c Hasil Pengamatan Pelaksanaan Pembelajaran

d Instrumen Penilaian dalam Pembelajaran

Hasil Penilaian Kinerja Guru Tersertifikasi sesuai tabel di atas dapat diketahui bahwa rata-rata PKG Tersertifikasi SMP Negeri Sinombayuga dalam Kompetensi pedagogik dan profesional masing-masing komponen yaitu : 1) Hasil Penilaian administrasi Perencanaan pembelajaran dengan nilai 92.50; 2) Hasil Telaah RPP dengan nilai 88.98; 3) Hasil Pengamatan Pelaksanaan Pembelajaran dengan nilai 88.98; dan 4) Instrumen Penilaian dalam Pembelajaran dengan nilai 85.71

Berdasarkan nilai PKG tersebut di atas dapat disimpulkan bahwa nilai tertinggi kinerja guru tersertifikasi adalah komponen penilaian administrasi Perencanaan pembelajaran dengan nilai 92.50, yang terdiri dari : 1) kalender pendidikan; 2) program tahunan; 3) program semester; 4) Rincian Pekan Efektif; 5) Analisis KI, KD, SKL; 6) Silabus \&RPP; 7) KKM; 8) Jadwal tatap muka; 9) Agenda Harian/Jurnal;dan 10) Absensi Siswa.

2. Kompetensi Kepribadian

Setiap guru tersertifikasi harus memiliki kompetensi kepribadian yang baik dengan indikator penilaian sebagaimana format dalam tabel berikut ini :

${ }^{32}$ Iam Kasiaradja, Kepala sekolah di SMP N Sinombayuga Kecamatan Posigadan, Wawancara, 2019. 


\section{Irfani}

ISSN 1907-0969 E ISSN 2442-8272

Volume 15 Nomor 1 Juni 2019

Halaman 98-121

http://journal.iaingorontalo.ac.id/index.php/ir

Tabel 6. Format Penilaian Kompetensi Kepribadian

\begin{tabular}{|c|c|c|c|}
\hline No. & $\begin{array}{l}\text { Kompetensi/Bukti Fisik dari } \\
\text { Indikator yang dinilai }\end{array}$ & Uraian/Kelengkapan Bukti Fisik & Skor \\
\hline 1 & 2 & 3 & 4 \\
\hline 1. & $\begin{array}{l}\text { Guru memberikan perlakuan } \\
\text { yang sama dan tidak } \\
\text { diskriminatif terhadap peserta } \\
\text { didik baik dalam kegiatan } \\
\text { pembelajaran maupun di luar } \\
\text { kegiatan pembelajaran. }\end{array}$ & $\begin{array}{ll}\text { - } & \text { Dilakukan dengan sangat baik } \\
\text { - } & \text { Dilakukan dengan baik } \\
\text { - } & \text { Dilakukan dengan kurang baik } \\
\text { - } & \text { Dilakukan dengan tidak baik }\end{array}$ & $\begin{array}{l}4 \\
3 \\
2 \\
1\end{array}$ \\
\hline 2. & $\begin{array}{l}\text { Ketaatan guru dalam } \\
\text { menjalankan ajaran agama } \\
\text { yang dianut, menjadi panutan } \\
\text { bagi peserta didik }\end{array}$ & $\begin{array}{ll}\text { - } & \text { Sangat baik } \\
\text { - } & \text { Baik } \\
\text { - } & \text { Kurang baik } \\
\text { - } & \text { Tidak baik }\end{array}$ & $\begin{array}{l}4 \\
3 \\
2 \\
1\end{array}$ \\
\hline 3. & $\begin{array}{l}\text { Guru berprilaku jujur, tegas } \\
\text { dan manusiawi baik terhadap } \\
\text { atasan, teman sejawat, peserta } \\
\text { didik maupun warga sekolah } \\
\text { lainnya. }\end{array}$ & $\begin{array}{ll}\text { - } & \text { Dilakukan dengan sangat baik } \\
\text { - } & \text { Dilakukan dengan baik } \\
\text { - } & \text { Dilakukan dengan kurang baik } \\
\text { - } & \text { Dilakukan dengan tidak baik }\end{array}$ & $\begin{array}{l}4 \\
3 \\
2 \\
1\end{array}$ \\
\hline 4. & $\begin{array}{l}\text { Guru berperilaku yang } \\
\text { mencerminkan ketaqwaan } \\
\text { dan akhlak mulia dalam } \\
\text { kesehariannya. }\end{array}$ & $\begin{array}{ll}\text { - } & \text { Dilakukan dengan sangat baik } \\
\text { - } & \text { Dilakukan dengan baik. } \\
\text { - } & \text { Dilakukan dengan kurang baik } \\
\text { - } & \text { Dilakukan dengan tidak baik } \\
\end{array}$ & $\begin{array}{l}4 \\
3 \\
2 \\
1\end{array}$ \\
\hline 5. & $\begin{array}{l}\text { Guru dapat memberi dan } \\
\text { menjadi contoh bagi peserta } \\
\text { didik, teman sejawat, dan } \\
\text { masyarakat dalam bersikap. } \\
\text { Misal: sikap rendah hati, } \\
\text { menghormati dan menghargai } \\
\text { orang lain, tutur kata yang } \\
\text { sopan, melaksanakan 4S, dll. }\end{array}$ & $\begin{array}{ll}\text { - } & \text { Sangat baik } \\
\text { - } & \text { Baik } \\
\text { - } & \text { Kurang baik } \\
\text { - } & \text { Tidak baik }\end{array}$ & $\begin{array}{l}4 \\
3 \\
2 \\
1\end{array}$ \\
\hline 6. & $\begin{array}{l}\text { Guru harus memiliki pribadi } \\
\text { yang mantap dan stabil. }\end{array}$ & $\begin{array}{l}\text { - Sangat mantap dan stabil. } \\
\text { - Mantab dan stabil } \\
\text { - Kurang mantap dan kurang stabil } \\
\text { - Tidak mantap dan tidak stabil }\end{array}$ & $\begin{array}{l}4 \\
3 \\
2 \\
1\end{array}$ \\
\hline
\end{tabular}




\section{Irfani}

ISSN 1907-0969 E ISSN 2442-8272

Volume 15 Nomor 1 Juni 2019

Halaman 98-121

http://journal.iaingorontalo.ac.id/index.php/ir

\begin{tabular}{|c|c|c|c|}
\hline No. & $\begin{array}{l}\text { Kompetensi/Bukti Fisik dari } \\
\text { Indikator yang dinilai }\end{array}$ & Uraian/Kelengkapan Bukti Fisik & Skor \\
\hline 7. & $\begin{array}{l}\text { Guru memiliki pribadi yang } \\
\text { dewasa, arif, dan berwibawa. }\end{array}$ & $\begin{array}{ll}\text { - } & \text { Sangat dewasa, arif dan } \\
\text { sangat berwibawa } \\
\text { - } & \text { Dewasa, arif, dan berwibawa } \\
\text { - } & \text { Kurang dewasa, kurang arif } \\
\text { dan kurang berwibawa } \\
\text { - } & \text { Tidak dewasa, tidak arif dan } \\
& \text { tidak berwibawa }\end{array}$ & $\begin{array}{l}4 \\
3 \\
2 \\
1\end{array}$ \\
\hline 8. & $\begin{array}{l}\text { Guru menunjukkan etos kerja } \\
\text { dan tanggung jawab yang } \\
\text { tinggi. Misal: bersemangat } \\
\text { melaksanakan dan mentaati } \\
\text { kaidah-kaidah dalam tugas, } \\
\text { melaksanakan pembelajaran } \\
\text { dengan baik dan sesuai } \\
\text { jadwal, dll. }\end{array}$ & $\begin{array}{ll}\text { - } & \text { Sangat tinggi } \\
\text { - } & \text { Tinggi } \\
\text { - } & \text { Cukup } \\
- & \text { Rendah }\end{array}$ & $\begin{array}{l}4 \\
3 \\
2 \\
1\end{array}$ \\
\hline 9. & $\begin{array}{l}\text { Guru mewujudkan komitmen } \\
\text { yang tinggi tentang } \\
\text { profesinya. Misal: bangga } \\
\text { bahwa menjadi seorang guru, } \\
\text { percaya diri, dll. }\end{array}$ & $\begin{array}{ll}\text { - } & \text { Sangat tinggi } \\
\text { - } & \text { Tinggi } \\
\text { - } & \text { Cukup } \\
- & \text { Rendah }\end{array}$ & $\begin{array}{l}4 \\
3 \\
2 \\
1\end{array}$ \\
\hline 10. & $\begin{array}{l}\text { Guru dapat mewujudkan } \\
\text { sikap kemandirian dan } \\
\text { profesionalisme. }\end{array}$ & $\begin{array}{ll}\text { - } & \text { Sangat baik } \\
\text { - } & \text { Baik } \\
\text { - } & \text { Sedang } \\
\text { - } & \text { Tidak baik }\end{array}$ & $\begin{array}{l}4 \\
3 \\
2 \\
1\end{array}$ \\
\hline 11. & $\begin{array}{l}\text { Guru dapat mewujudkan } \\
\text { ketaatan diri akan kode etik } \\
\text { profesi guru. }\end{array}$ & $\begin{array}{ll}\text { - } & \text { Sangat baik } \\
\text { - } & \text { Baik } \\
\text { - } & \text { Sedang } \\
\text { - } & \text { Tidak baik }\end{array}$ & $\begin{array}{l}4 \\
3 \\
2 \\
1\end{array}$ \\
\hline 12. & $\begin{array}{l}\text { Guru dapat melaksanakan } \\
\text { kode etik profesi guru dalam } \\
\text { kehidupan sehari-hari. }\end{array}$ & $\begin{array}{ll}\text { - } & \text { Sangat baik } \\
\text { - } & \text { Baik } \\
\text { - } & \text { Sedang } \\
\text { - } & \text { Tidak baik } \\
\end{array}$ & $\begin{array}{l}4 \\
3 \\
2 \\
1\end{array}$ \\
\hline 13. & $\begin{array}{l}\text { Guru dapat mewujudkan } \\
\text { sikap, perilaku, dan ucapan } \\
\text { sesuai kode etik guru. }\end{array}$ & $\begin{array}{ll}\text { - } & \text { Sangat baik } \\
\text { - } & \text { Baik } \\
\text { - } & \text { Sedang } \\
\text { - } & \text { Tidak baik } \\
\end{array}$ & $\begin{array}{l}4 \\
3 \\
2 \\
1\end{array}$ \\
\hline & JUMLAH & & ....... \\
\hline
\end{tabular}




\section{Irfani}

ISSN 1907-0969 E ISSN 2442-8272

Volume 15 Nomor 1 Juni 2019

Halaman 98-121

http://journal.iaingorontalo.ac.id/index.php/ir

\begin{tabular}{|l|l|l|l|}
\hline No. & $\begin{array}{l}\text { Kompetensi/Bukti Fisik dari } \\
\text { Indikator yang dinilai }\end{array}$ & Uraian/Kelengkapan Bukti Fisik & Skor \\
\hline & \multicolumn{2}{|l|}{ Nilai Kompetensi Kepribadian ( NKK ) } & $\ldots \ldots .$. \\
\hline
\end{tabular}

Sumber data : SMP Negeri Sinombayuga, 22-01- 2020

Keterangan angka pada kolom skor $(1,2,3,4)$ sesuai dengan kriteria sebagai berikut:

$1=$ Tidak baik

$2=$ Cukup/Sedang

$3=$ Baik

$4=$ Sangat baik

Hasil PKG Kompetensi Kepribadian tersertifikasi di SMP Negeri Sinombayuga yang terdiri dari 13 indikator di atas, sebagai berikut :

Tabel 7. Hasil Penilaian Kompetensi Kepribadian

\begin{tabular}{|c|l|c|c|c|}
\hline No. & \multicolumn{1}{|c|}{ N a m a } & Skor & $\%$ & Kriteria \\
\hline 1. & Kristian Ointu, S.Pd. & 49 & 94.23 & Sangat Baik \\
\hline 2. & Harmus Pakaya & 46 & 88.46 & Sangat Baik \\
\hline 3. & Fitriana Lemba, S.Pd. & 48 & 92.30 & Sangat Baik \\
\hline \multicolumn{2}{r|}{ Jumlah } & 142 & 91.66 & Sangat Baik \\
\hline
\end{tabular}

Sumber data : Penilaian Kepala SMP Negeri Sinombayuga, 20-01-2020.

Keterangan kriteria setiap indikator Kompetensi Kepribadian sebagai berikut :

skor maksimal $=4 \times 13=52$

Skor minimal $=1 \times 13=13$

Dari hasil penilaian Kompetensi Kepribadian (NKK) guru tersertifikasi di SMP Negeri Sinombayuga memiliki skor sebesar 142 atau 91,66. Sehingga dapat disimpulkan bahwa kompetensi kepribadian guru tersertifikasi di SMP Negeri Sinombayuga termasuk dalam kategori nilai sangat baik.

3. Kompetensi Sosial

Setiap guru tersertifikasi harus memiliki kompetensi sosial dengan indikator penilaian sebagaimana format dalam tabel berikut ini :

Tabel 8. Format Penilaian Kompetensi Sosial

\begin{tabular}{|c|l|l|c|}
\hline No & $\begin{array}{c}\text { Kompetensi/Bukti Fisik dari } \\
\text { Indikator yang dinilai }\end{array}$ & $\begin{array}{c}\text { Uraian/Kelengkapan } \\
\text { Bukti Fisik }\end{array}$ & Skor \\
\hline $\mathbf{1}$ & \multicolumn{1}{|c|}{$\mathbf{2}$} & \multicolumn{1}{|c|}{$\mathbf{3}$} & $\mathbf{4}$ \\
\hline 1. & Dalam Pembelajaran Guru & Sangat baik & 4 \\
& bersikap inklusif dan obyektif & Baik & 3 \\
& terhadap peserta didik & Sedang & 2 \\
& & Tidak baik & 1 \\
\hline
\end{tabular}




\section{Irfani}

ISSN 1907-0969 E ISSN 2442-8272

Volume 15 Nomor 1 Juni 2019

Halaman 98-121

http://journal.iaingorontalo.ac.id/index.php/ir

\begin{tabular}{|c|c|c|c|}
\hline No & $\begin{array}{l}\text { Kompetensi/Bukti Fisik dari } \\
\text { Indikator yang dinilai }\end{array}$ & $\begin{array}{c}\text { Uraian/Kelengkapan } \\
\text { Bukti Fisik }\end{array}$ & Skor \\
\hline 2. & $\begin{array}{l}\text { Guru memberikan perlakuan } \\
\text { yang sama dan demokratis } \\
\text { terhadap peserta didik }\end{array}$ & $\begin{array}{l}\text { Sangat baik } \\
\text { Baik } \\
\text { Sedang } \\
\text { Tidak baik }\end{array}$ & $\begin{array}{l}4 \\
3 \\
2 \\
1\end{array}$ \\
\hline 3. & $\begin{array}{l}\text { Guru dapat mewujudkan } \\
\text { interaksi dan komunikatif yang } \\
\text { baik dengan peserta didik }\end{array}$ & $\begin{array}{l}\text { Sangat baik } \\
\text { Baik } \\
\text { Sedang } \\
\text { Tidak baik }\end{array}$ & $\begin{array}{l}4 \\
3 \\
2 \\
1\end{array}$ \\
\hline 4. & $\begin{array}{l}\text { Guru dapat melayani orang tua } \\
\text { peserta didik dan masyarakat } \\
\text { secara baik dan ramah. }\end{array}$ & $\begin{array}{l}\text { Sangat baik } \\
\text { Baik } \\
\text { Sedang } \\
\text { Tidak baik }\end{array}$ & $\begin{array}{l}4 \\
3 \\
2 \\
1\end{array}$ \\
\hline 5. & $\begin{array}{l}\text { Guru dapat mewujudkan } \\
\text { kerjasama yang baik dengan } \\
\text { orang tua peserta didik, dan } \\
\text { masyarakat dalam mengatasi } \\
\text { kesulitan belajar peserta didik. }\end{array}$ & $\begin{array}{l}\text { Sangat baik } \\
\text { Baik } \\
\text { Sedang } \\
\text { Tidak baik }\end{array}$ & $\begin{array}{l}4 \\
3 \\
2 \\
1\end{array}$ \\
\hline 6. & $\begin{array}{l}\text { Guru dapat mewujudkan } \\
\text { interaksi dan komunikatif yang } \\
\text { baik dengan orang tua peserta } \\
\text { didik, dan masyarakat setempat. }\end{array}$ & $\begin{array}{l}\text { Sangat baik } \\
\text { Baik } \\
\text { Sedang } \\
\text { Tidak baik }\end{array}$ & $\begin{array}{l}4 \\
3 \\
2 \\
1\end{array}$ \\
\hline 7. & $\begin{array}{l}\text { Guru dapat mewujudkan } \\
\text { partisipasi dalam berbagai } \\
\text { kegiatan di sekolah untuk } \\
\text { menyalurkan bakat dan minat } \\
\text { peserta didik }\end{array}$ & $\begin{array}{l}\text { Ada: lebih dari } 10 \\
\text { Ada: } 6-10 \\
\text { Ada: } 3-5 \\
\text { Ada: } 1-2 \\
\text { Tidak ada }\end{array}$ & $\begin{array}{l}4 \\
3 \\
2 \\
1 \\
0\end{array}$ \\
\hline & JUMLAH & & -..... \\
\hline & \multicolumn{2}{|c|}{ Nilai Kompetensi Sosial ( NKS ) } & ........ \\
\hline
\end{tabular}

Sumber data : Penilaian Kepala SMP Negeri Sinombayuga, 20-01-2020 


\section{Irfani}

ISSN 1907-0969 E ISSN 2442-8272

Volume 15 Nomor 1 Juni 2019

Halaman 98-121

http://journal.iaingorontalo.ac.id/index.php/ir

Keterangan angka pada kolom skor $(1,2,3,4)$ sesuai dengan kriteria sebagai berikut:

$1=$ Tidak baik

$2=$ Cukup/Sedang

3 = Baik

$4=$ Sangat baik

Hasil NKS guru tersertifikasi di SMP Negeri Sinmobayuga yang terdiri dari 7 indikator di atas, dapat di lihat pada tabel sebagai berikut :

Tabel 9. Hasil Penilaian Kompetensi Sosial

\begin{tabular}{|c|l|c|c|c|}
\hline No. & \multicolumn{1}{|c|}{ N a m a } & Skor & $\%$ & Kriteria \\
\hline 1. & Kristian Ointu, S.Pd. & 27 & 96.43 & Sangat Baik \\
\hline 2. & Harmus Pakaya & 25 & 89.29 & Sangat Baik \\
\hline 3. & Fitriana Lemba, S.Pd. & 26 & 92.86 & Sangat Baik \\
\hline \multicolumn{2}{|c|}{ Jumlah } & 78 & 92.86 & Sangat Baik \\
\hline
\end{tabular}

Sumber data : Penilaian Kepala SMP Negeri Sinombayuga, 20-01-2020

Keterangan kriteria setiap indikator Kompetensi Kepribadian sebagai berikut :

skor maksimal $=4 \times 7=28$

Skor minimal $=1 \times 7=7$

Dari hasil penilaian Kompetensi Sosial (NKS) guru tersertifikasi di SMP Negeri Sinombayuga memiliki skor sebesar 78 atau 92,86. Sehingga dapat disimpulkan bahwa kompetensi sosial guru tersertifikasi di SMP Negeri Sinombayuga termasuk dalam kategori nilai sangat baik.

\section{KESIMPULAN}

Kinerja guru tersertifikasi di SMP N Sinombayuga Kecamatan Posigadan. Guru yang bersertifikasi yang dikatakan profesional harus memiliki kemampuan menguasai bidang pedagogik, bidang sosial, bidang kepribadian, dan bidang profesional. Implementasi kinerja guru tersertifikasi dalam pengelolaan pembelajaran di SMP Negeri Sinombayuga Kecamatan Posigadan, berdasarkan hasil Penilaian Kinerja Guru (PKG) pada semester Ganjil Tahun Pelajaran 2019/2020, sebagai berikut :

1) Hasil Penilaian kompotensi pedagogik dan profesional dari keseluruhan komponen yang dinilai rata-rata 88.68 (Sangat Baik), dengan masing-masing indikator ; a) Hasil Penilaian administrasi Perencanaan pembelajaran 92.50; b) Hasil telaah RPP 88.98; c) Hasil Pengamatan Pelaksanaan Pembelajaran 88.85 ; dan d) Instrumen Penilaian dalam Pembelajaran 85.71.

2) Hasil penilaian Kompetensi Kepribadian guru tersertifikasi di SMP Negeri Sinombayuga 91,66 (Sangat Baik) 


\section{Irfani}

ISSN 1907-0969 E ISSN 2442-8272

Volume 15 Nomor 1 Juni 2019

Halaman 98-121

http://journal.iaingorontalo.ac.id/index.php/ir

3) Hasil penilaian Kompetensi Sosial guru tersertifikasi di SMP Negeri Sinombayuga 92,86 (Sangat Baik)

\section{DAFTAR PUSTAKA}

Daryanto, Media Pembelajaran, Yogyakarta: Gava Media, 2010.

Erwinsyah, Alfian. Manajemen Pembelajaran dalam Kaitannya dengan Peningkatan Kualitas Guru, “Tadbir” Jurnal Manajemen Pendidikan Islam Volume 5 No. 1 Februari 2017.

Manoppo, Yanty K. Analisis penerapan standar proses pembelajaran Pendidikan Agama Islam di SMP Negeri 2 Kota Gorontalo, Jurnal Manajemen Pendidikan Islam Volume 2 No. 2 Agustus 2014.

Majid, Abdul. Perencanaan Pembelajaran (Mengembangkan Standar Kompetensi Guru). Bandung: Remaja Rosdakarya.

Mulyasa, E. Standar Kompetensi dan Sertifikasi guru, Bandung: Rosdakarya, 2008.

Menjadi Guru Profesional. Menciptakan Pembelajaran Kreatif dan Menyenangkan. Bandung: PT Remaja Rosdakarya, 2007.

Musfah , Peningkatan Kompetensi Guru melalui Pelatihan dan Sumber Belajar Teori dan Praktik. Jakarta: Prenadamedia Group, 2015.

Munthe, Bermawi. Desain Pembelajaran, Yogyakarta: Pustaka Insan Madani, 2009.

Rohani, Ahmad. Pengelolaan Pembelajaran. Jakarta: PT Rineka Cipta. 2004.

Sugihartono, dkk.Psikologi Pendidikan Cet-1. Yogyakarta: UNY Press, 2007.

Suryosubroto, Proses Belajar Mengajar Di Sekolah. Wawasan Baru, Beberapa Metode Pendukung dan Beberapa Komponen Layanan Khusus. Jakarta: PT Rineka Cipta. 2009.

Suprahatiningrum. Jamil. Guru Profesional.Yogyakarta: Ar-Ruzz Media, 2014.

Siti Asiah T., Efektivitas Kinerja Guru, Tadbir" Jurnal Manajemen Pendidikan Islam Volume 5 No. 2 Agustus 2016,

Sudarmanto, Kinerja dan Pengembangan Kompetensi SDM. Yogyakarta: Pustaka Pelajar, 2009.

Undang-Undang RI nomor 14 Tahun 2005 tentang Guru dan Dosen Pasal7 cet.11,,Bandung: Pustaka Pelajar, 2009.

Usman, Mohd. Uzer. Menjadi Guru Profesional, Bandung: PT. Remaja Rosdakarya, 2003.

Wahyudi, Iman. Panduan Uji Sertifikasi Guru Sertifikasi. Jakarta: PT. Prestasi Pustakaraya, 2012.

Yusrizal, dkk., Evaluasi Kinerja Guru Fisika, Biologi dan Kimia SMA yang Sudah Lulus Sertifikasi, Jurnal Penelitian dan Evaluasi Pendidikan Universitas Syiah Kuala, Tahun 15, Nomor 2, 2011. 